\title{
Responses of Taxus chinensis and Phoebe chekiangensis seedlings to controlled-release fertilizer in various formulations and application
}

\section{rates}

\author{
Xiuli Chu ${ }^{(1)}$, \\ Xiuhua Wang ${ }^{(2)}$, \\ Dongbei Zhang ${ }^{(2)}$, \\ Xiaolin $\mathrm{Wu}^{(2)}$, \\ Zhichun Zhou ${ }^{(1)}$
}

\begin{abstract}
Decline of species population, low natural regeneration, and heavy competition on field sites require the planting of large seedling stocks to restore Taxus chinensis and Phoebe chekiangensis in tropical China. In this study, we examined the effects of different formulations and application rates of controlled-release fertilizers (CRF) of nitrogen (N) and phosphorus (P) on nursery seedling growth and nutritional attributes. The objective was to determine optimum formulation $\left(\mathrm{N}: \mathrm{P}_{2} \mathrm{O}_{5}\right.$ ratio) and application rate to increase nutrient reserves of the seedlings before transplanting to the field. Four formulations (17-9-13 to 19-6-14 N-P $\mathrm{O}_{5}-\mathrm{K}_{2} \mathrm{O}$ ratios) and four application rates $\left(1.5 \mathrm{~kg} \mathrm{~m}^{-3}\right.$ to $4.5 \mathrm{~kg} \mathrm{~m}^{-3}$ ) were used in a double-factors factorial design with 3 replications. The results showed that CRF formulation can affect nutritional attributes, while application rate modified seedling growth and nutritional attributes. The optimum seedling response occurred with the 17-6-16 formulation at the rate of $3.5 \mathrm{~kg} \mathrm{~m}^{-3}$. These findings will guide nursery practice in the production of high-quality seedlings for optimum survival and growth in the field.
\end{abstract}

Keywords: Taxus chinensis, Phoebe chekiangensis, Controlled-release Fertilizer, Formulation and Application Rate, Nutrient Utilization Efficiency

\section{Introduction}

Taxus chinensis [Pilg.] Rehd. (common name: Chinese yew) and Phoebe chekiangensis Shang (common name: Zhejiang Phoebe) are two slow-growing tree species native to tropical China (Deng et al. 2008, Thomas et al. 2013, Zang et al. 2017). The main usage of these species is to harvest timber for manufacture of high end furniture, especially with Zhejiang Phoebe (Wang et al. 2013, Zang et al. 2017). Since the 1990s, natural Chinese yew seeds have been targeted to extract toxoids for the treatment of cancer (Chen et al. 1999). The pharmaceutical use of Chinese yew has heavily impacted the natural populations with a sharp decrease of natural reserves (Thomas et al. 2013), which stimulated the commercial development of this species. Under natural conditions, regeneration of these two species is very difficult (Zang et al. 2017), possibly due to constraints from intense seed dormancy, limited seed dis- persal, susceptibility to seed rot, possible animal grazing, and the seed requirements for high moisture and low light during germination, seedling establishment, and early growth (Deng et al. 2008, Zang et al. 2017). Global climate change may also disfavor the natural regeneration of these two species by higher temperatures and increasing drought (Yu et al. 2014, He et al. 2017, Jia \& Liu 2017). As a result, both species have been classified as "endangered" in the Red List Category by the International Union for Conservation of $\mathrm{Na}$ ture (IUCN - World Conservation Monitoring Centre 1998, Thomas et al. 2013). Seedling planting is therefore required for sustaining natural populations and restoring forests for timber harvest (Deng et al. 2008, Zang et al. 2017), especially with the use of competitive seedlings (Wang et al. 2013, Xiao et al. 2015).

Container stock seedlings are superior to bare-root seedlings in terms of survival and growth (Yuan et al. 2012, Wang et al. 2013) The use of polymer-coated controlled-release fertilizer (CRF) at time of planting can promote seedling survival (Irino et al. 2005, Oskarsson et al. 2006, Fu et al. 2017) and early growth (Huat et al. 2002, Hawkins et al. 2005, Irino et al. 2005, Jacobs et al. 2005, Oskarsson et al. 2006, Ruthrof et al. 2010, Burney \& Jacobs 2011, Sloan \& Jacobs 2013, Fu et al. 2017). It is especially useful to employ CRF to seedlings in the face of harsh site conditions, such as intensive vegetation competition, poor soil nutrient availability, and heavy canopy shade (Devine et al. 2007, Burney \& Jacobs 2011, Sloan \& Jacobs 2012, Earnshaw et al. 2016). These types of sites are especially hard to reforest with endangered tree species because these species typically grow slower than competitors and are more sensitive to field conditions (Wang et al. 2013).

CRF can also be used to enhance nursery seedling quality through nutrition-loading

$\square$ (1) Research Institute of Subtropical Forestry, Chinese Academy of Forestry; Zhejiang Provincial Key Laboratory of Tree Breeding, 311400 , Hangzhou (China); (2) Experimental Forest Farm of Qingyuan County, Zhejiang Province, Qingyuan 323800, Zhejiang (China)

@ Zhichun Zhou (412532937@qq.com)

Received: Dec 20, 2017 - Accepted: Feb 01, 2019

Citation: Chu X, Wang X, Zhang D, Wu X, Zhou Z (2019). Responses of Taxus chinensis and Phoebe chekiangensis seedlings to controlledrelease fertilizer in various formulations and application rates. iForest 12: 254-261. - doi: 10.3832/ifor2714-012 [online 2019-05-03] 
before transplanting (Irino et al. 2004, Zamunér Filho et al. 2012, Klooster et al. 2012, An et al. 2018). In southern nurseries of China, one of the widely-used CRFs by nursery managers is Apex $^{\mathrm{TM}}$ (J.R. Simplot Company, USA) which contains nitrogen $(\mathrm{N})$, phosphorus $\left(\mathrm{P}, \mathrm{P}_{2} \mathrm{O}_{5}\right)$, and potassium $(\mathrm{K}$, $\mathrm{K}_{2} \mathrm{O}$ ) in a ratio of $18-8-8$ and is typically applied at $2.5 \mathrm{~kg} \mathrm{~m}^{-3}$. This CRF application rate is often supplemented with the application of urea and ammonium phosphate to promote seedling growth. The current formulation and application rate with Apex for container seedlings is largely based on empirical observations, thus significant knowledge gaps exist in terms of the scientific employment of CRF with respect to inherent nutrient uptake and utilization by target seedlings.

There is supporting evidence that seedlings with enhanced nutrient reserves are expected to exhibit increased survival and growth after field transplanting (Reddell et al. 1999, Duan et al. 2013, Wei et al. 2013, Fu et al. 2017, Li et al. 2017), through improved nutrient uptake and enhanced photosynthesis (Irino et al. 2004, Morikawa et al. 2006, Klooster et al. 2012). Among all the elements required by tree seedlings, $\mathrm{N}$ and $\mathrm{P}$ are the most limiting and therefore generally contained in CRF application (Oskarsson et al. 2006, Ruthrof et al. 2010, Klooster et al. 2012, Sloan \& Jacobs 2013, Earnshaw et al. 2016, Zhu et al. 2016, Fu et al. 2017). Both CRF formulation (namely, $\mathrm{N}: \mathrm{P}_{2} \mathrm{O}_{5}$ ratio) and application rate influence seedling performances (Oliet et al. 2004, Xiao et al. 2015, Li et al. 2017), but the suggested empirical formulation for optimum growth from previous reports is highly variable (Oliet et al. 2004, Zhao et al. 2010, Chu et al. 2012). In fact, little information is available regarding the optimum combina-

Tab. 1 - Formulation (F) and application rate (A) of controlled-release fertilizers for Chinese yew and Phoebe chekiangensis seedlings.

\begin{tabular}{|c|c|c|c|c|c|}
\hline $\begin{array}{l}\text { Formulation } \\
\text { treatment }\end{array}$ & $\begin{array}{c}\mathrm{N}-\mathrm{P}_{2} \mathrm{O}_{5}-\mathrm{K}_{2} \mathrm{O} \\
\text { ratio }\end{array}$ & $\begin{array}{c}\text { Application } \\
\text { treatment }\end{array}$ & $\begin{array}{l}\text { Application } \\
\text { rate } \\
\left(\mathrm{kg} \mathrm{m}^{-3}\right)\end{array}$ & $\begin{array}{c}\text { N rate } \\
\left(\text { g plant }^{-1}\right)\end{array}$ & $\begin{array}{c}\text { P rate } \\
\left(\text { ( plant }^{-1}\right)\end{array}$ \\
\hline \multirow{4}{*}{$\mathrm{F} 1$} & \multirow{4}{*}{$17-9-13$} & $\mathrm{~A} 1$ & 1.5 & 1.30 & 0.69 \\
\hline & & A2 & 2.5 & 2.16 & 1.14 \\
\hline & & $\mathrm{A} 3$ & 3.5 & 3.03 & 1.60 \\
\hline & & A4 & 4.5 & 3.89 & 2.06 \\
\hline \multirow{4}{*}{$\mathrm{F} 2$} & \multirow{4}{*}{$16-7-16$} & $\mathrm{~A} 1$ & 1.5 & 1.30 & 0.69 \\
\hline & & $\mathrm{A} 2$ & 2.5 & 2.16 & 1.14 \\
\hline & & $\mathrm{A} 3$ & 3.5 & 3.03 & 1.60 \\
\hline & & A4 & 4.5 & 3.89 & 2.06 \\
\hline \multirow{4}{*}{ F3 } & \multirow{4}{*}{$17-6-16$} & $\mathrm{~A} 1$ & 1.5 & 1.30 & 0.69 \\
\hline & & $\mathrm{A} 2$ & 2.5 & 2.16 & 1.14 \\
\hline & & A3 & 3.5 & 3.03 & 1.60 \\
\hline & & A4 & 4.5 & 3.89 & 2.06 \\
\hline \multirow{4}{*}{$\mathrm{F} 4$} & \multirow{4}{*}{$19-6-14$} & $\mathrm{~A} 1$ & 1.5 & 1.30 & 0.69 \\
\hline & & $\mathrm{A} 2$ & 2.5 & 2.16 & 1.14 \\
\hline & & $\mathrm{A} 3$ & 3.5 & 3.03 & 1.60 \\
\hline & & A4 & 4.5 & 3.89 & 2.06 \\
\hline
\end{tabular}

ing substrate (peat and bran in 7:3 in volume) mixed with $2.5 \mathrm{~kg} \mathrm{Apex}{ }^{\mathrm{TM}}$ (J.R. Simplot Company, USA) per cubic meter. The substrate for CRF treatments was a mixture of peat, chaff, and mineral soil (40\%:30\%:30\% in volume). The mixture had total $\mathrm{N}$ of $14.2 \mathrm{~g} \mathrm{~kg}^{-1}$, total $\mathrm{P}$ of $0.7 \mathrm{~g} \mathrm{~kg}^{-1}$, total potassium (K) of $2.7 \mathrm{~g} \mathrm{~kg}^{-1}$, bulk density of $0.3 \mathrm{~g} \mathrm{~cm}^{-3}$, and $\mathrm{pH}$ of 6.0. Using an automated irrigation system, seeded substrates were watered twice a day (10-15 minutes in the morning and evening) except for rainy days. In early December, the seedlings reached an average height of $43 \mathrm{~cm}$ and root-collar diameter (RCD) of $4.34 \mathrm{~mm}$ for Chinese yew, and an average height of 31 $\mathrm{cm}$ and RCD of $4.58 \mathrm{~mm}$ for Zhejiang Phoebe, based on random samples of 20 seedlings per species. The measurements of the 20 random samples indicated the total seedling $\mathrm{N}$ and $\mathrm{P}$ of $5.14 \mathrm{mg}$ and $1.87 \mathrm{mg}$ for Chinese yew and of $9.94 \mathrm{mg}$ and $4.50 \mathrm{mg}$ for Zhejiang Phoebe, respectively.

\section{Study site}

The study was conducted in the experimental forest nursery $\left(27^{\circ} 38^{\prime} \mathrm{N}, 119^{\circ} 01^{\prime} \mathrm{E}\right)$ at Qingyuan, Zhejiang, China. The study site belongs to the sub-tropical monsoon region, with elevation of $510 \mathrm{~m}$ a.s.l., mean annual temperature of $17.6{ }^{\circ} \mathrm{C}$, mean annual precipitation of $1721.3 \mathrm{~mm}$, and frostfree growing season of 245 days. The experiment was set up in an open steel greenhouse equipped with an automated irrigation system. The greenhouse was 2.2 $\mathrm{m}$ from ground to roof and had an average light transmittance around 50\%.

\section{Study material}

In late April of 2013, Chinese yew and Zhejiang Phoebe seedlings (40 days old after germination) were transplanted into nonwoven fabric containers of $5 \mathrm{~cm}$ diameter $x$ $10 \mathrm{~cm}$ height that were filled with a grow-

\section{CRF treatment}

On April 21, 2014, the two-year-old seedlings were transplanted into larger non-woven fabric pots $(18 \mathrm{~cm}$ diameter $\times 20 \mathrm{~cm}$ height). CRF granules (Jinzhengda Co. Ltd., Shandong, China), which should provide a continuous supply of nutrients for 6-7 months at $20^{\circ} \mathrm{C}$, were incorporated into the potting substrates. The CRF treatments followed a two-way factorial design with four levels of formulation and four levels of application rate. The four formulations ( $F$ ) differed in concentrations of $\mathrm{N}: \mathrm{P}_{2} \mathrm{O}_{5}: \mathrm{K}_{2} \mathrm{O}$ (Tab. 1) with four $\mathrm{N}: \mathrm{P}_{2} \mathrm{O}_{5}$ ratios ranging from $17: 9$ (F1, reference level) to 19:6 (F4, emulating summer application of additional urea and ammonium phosphate at nursery). The four application rates (A) ranged from 1.5 $\mathrm{kg} \mathrm{m}^{-3}$ (A1) to $4.5 \mathrm{~kg} \mathrm{~m}^{-3}$ (A4), with the 2.5 $\mathrm{kg} \mathrm{m}^{-3}\left(\mathrm{~A}_{2}\right)$ being considered a standard rate in southeast China nurseries. The lowest application rate (A1) was designed as a baseline to obtain comparable seedling performance at reduced CRF, while the highest rate $\left(\mathrm{A}_{4}\right)$ was to evaluate possible gain from enhanced fertilization. These treatments were replicated three times with thirty seedlings assigned to each combination of formulations and application rates. In total, 1440 seedlings ( 4 formulations $\times 4$ rates $\times 3$ replications $\times 30$ seedlings) were tested for each species. Fans and curtains were used to increase air movement and reduce sunlight when temperatures were above $30{ }^{\circ} \mathrm{C}$ during the experiment.

\section{Seedling harvest, measurement and statistical analysis}

Seedlings were destructively sampled in early December when current growth was complete. Ten randomly-selected seedlings from each treatment combination were measured for height $(\mathrm{cm})$ and RCD $(\mathrm{mm})$ and destructively sampled. For biomass determination, each of the sampled seedlings were washed, separated into leaves, stems 
and roots, and oven-dried for three days at $68{ }^{\circ} \mathrm{C}$. The dried samples were then ground and sieved through $1.5 \mathrm{~mm}$-mesh, and digested with $\mathrm{H}_{2} \mathrm{SO}_{4}-\mathrm{H}_{2} \mathrm{O}_{2}$ (Xiao et al. 2015). $\mathrm{N}$ and $\mathrm{P}$ concentrations were determined using the Kjeldahl method (Xiao et al. 2015) and ICP-OES (Vista-Mpx, Varian ${ }^{\oplus}$, USA), respectively (Wei et al. 2013).

The Dickson's seedling quality index (DQI) (Dickson et al. 1960) was chosen to provide an integrated seedling quality assessment (Li et al. 2017 - eqn.1):

$$
D Q I=\frac{B A P}{(\text { Height } / R C D)+(S B / R B)}
$$

where $B A P$ is the total seedling biomass (g), SB is the shoot biomass (g), and RB is the root biomass ( $\mathrm{g}$ ).

Nutrient utilization index (UI) was used to evaluate photosynthetic production per unit leaf nutrient mass (Hawkins 2007 eqn. 2):

$$
U I=\frac{B A P}{\% C_{\text {leaf }}}
$$

where $\mathrm{UI}$ is N/P utilization index (NUI/PUI), and $\% C_{\text {leaf }}$ is percent leaf nutrient concentration.

Nutrient ( $\mathrm{N}$ or $\mathrm{P}$ ) recovery $\left(C_{\text {recovery }}\right)$ was calculated using the following equation (eqn. 3):

$$
C_{\text {recovery }}=\frac{C_{\text {uptake }}-C_{\text {initial }}}{C_{\text {fertilizer }}} \cdot 100
$$

where $C_{\text {uptake }}$ is the seedling nutrient total $(\mathrm{mg})$ at end of the treatments, $C_{\text {initial }}$ is the seedling nutrient total prior to CRF treatment (mg), and $C_{\text {fertilizer }}$ is the total nutrient supply from CRF.

The utilization efficiency of nutrient uptake by mass input to root (EuU) was calculated for $\mathrm{N}(E N U U)$ and $\mathrm{P}(E P U U$ - eqn. 4):

$$
E u U=\frac{C_{\text {uptake }}}{R B}
$$

Data analyses followed a two-way factorial design with four levels of CRF formulation and four application rates using the GLM procedure available in SAS (SAS Institute Inc., NC, USA). Measured response variables included height, RCD, total biomass, biomass allocations (component biomass to seedling biomass ratio), R/S ratio (root to stem biomass ratio), DQI (Dickson seedling quality index), $\mathrm{N}$ and $\mathrm{P}$ concentrations, and $\mathrm{N}$ and $\mathrm{P}$ uptake (seedling total) and allocations (ratios by biomass components). Means were compared with the post-hoc Tukey test when treatment effects were significant. When interactive effects of formulation by application rate were significant, data were re-analyzed with one-way ANOVA of sixteen treatments (four formulations by four application rates). Pearson's correlation was calculated among response variables of seedling growth, biomass, nutrient uptake and utilizations.

\section{Results}

\section{Growth and biomass}

The CRF formulation only affected the stem biomass allocation of Chinese yew seedlings (Tab. 2), with values significantly lower in the F4 (mean \pm SE: $38.88 \pm 3.18 \%$ ) than in the F1 $(42.20 \pm 2.10 \%), F_{2}(41.14 \pm$ $2.63 \%)$ or F3 $(42.07 \pm 3.46 \%)$ treatment. Comparatively, the impact of application rate was greater, affecting most of the growth and biomass variables of the two species (Tab. 2). The highest growth and biomass were observed in the $A_{3}$ treatment, which included height, RCD, seedling biomass and $D Q I$ of Chinese yew seedlings, and height and seedling biomass of Zhejiang Phoebe seedlings (Tab. 3). The CRF rate also affected stem and root biomass allocations and the root to shoot biomass ratio $(R / S)$ of Zhejiang Phoebe seedlings, with the mean value significantly greater in the $A 1$ treatment for root biomass allocation and $\mathrm{R} / \mathrm{S}$, and in the $\mathrm{A} 4$ treatment for stem biomass allocation (Tab. 3).

\section{Nutritional attributes}

In both species, $\mathrm{N}$ and $\mathrm{P}$ concentrations and uptakes generally peaked at $\mathrm{F}_{3}$ (Tab. 2, Fig. 1). The effect of application rate varied with species, nutrient type, and biomass component (Fig. 1), as well as with $\mathrm{N}: \mathrm{P}_{2} \mathrm{O}_{5}$

Tab. 2 - $P$ values from ANOVA on the effects of different formulations ( $F$ ) and application rates $(A)$ of controlled-release fertilizers on the growth and nutrient attributes of Taxus chinensis and Phoebe chekiangensis seedlings. (RCD): root collar diameter; (Leaf biomass allocation): leaf biomass to seedling biomass ratio; $(R / S)$ : root to shoot biomass ratio; (DQI): Dickson's seedling quality index; (Leaf $\mathrm{N}$ allocation): leaf total $\mathrm{N}$ to seedling total $\mathrm{N}$ ratio.

\begin{tabular}{lrrrrrr}
\hline \multirow{2}{*}{ Variables } & \multicolumn{3}{c}{ Taxus chinensis } & \multicolumn{3}{c}{ Phoebe chekiangensis } \\
\cline { 2 - 7 } & \multicolumn{1}{c}{ F } & \multicolumn{1}{c}{ A } & F $\times$ A & \multicolumn{1}{c}{ F } & \multicolumn{1}{c}{ A } & F $\times$ A \\
\hline Height & 0.098 & $<0.001$ & 0.844 & 0.101 & $<0.001$ & 0.829 \\
\hline RCD & 0.077 & $<0.001$ & 0.165 & 0.589 & 0.088 & 0.292 \\
\hline Seedling biomass & 0.200 & $<0.001$ & 0.607 & 0.297 & $<0.001$ & 0.219 \\
\hline Leaf biomass allocation \% & 0.884 & 0.966 & 0.243 & 0.128 & 0.064 & 0.550 \\
\hline Stem biomass allocation \% & 0.030 & 0.274 & 0.578 & 0.736 & 0.001 & 0.068 \\
\hline Root biomass allocation \% & 0.199 & 0.649 & 0.703 & 0.211 & $<0.001$ & 0.094 \\
\hline R/S & 0.141 & 0.274 & 0.897 & 0.169 & $<0.001$ & 0.140 \\
\hline DQI & 0.484 & $<0.001$ & 0.914 & 0.808 & 0.141 & 0.481 \\
\hline Leaf N concentration & 0.002 & $<0.001$ & $<0.001$ & $<0.001$ & $<0.001$ & 0.011 \\
\hline Stem N concentration & $<0.001$ & $<0.001$ & $<0.001$ & $<0.001$ & $<0.001$ & 0.002 \\
\hline Root N concentration & $<0.001$ & $<0.001$ & $<0.001$ & $<0.001$ & $<0.001$ & $<0.001$ \\
\hline Leaf P concentration & $<0.001$ & $<0.001$ & $<0.001$ & $<0.001$ & 0.026 & 0.024 \\
\hline Stem P concentration & $<0.001$ & $<0.001$ & $<0.001$ & $<0.001$ & $<0.001$ & $<0.001$ \\
\hline Root P concentration & $<0.001$ & 0.001 & $<0.001$ & $<0.001$ & $<0.001$ & 0.001 \\
\hline Seedling total N uptake & 0.359 & $<0.001$ & 0.047 & $<0.001$ & $<0.001$ & 0.423 \\
\hline Leaf N allocation \% & $<0.001$ & 0.158 & 0.192 & 0.008 & 0.033 & 0.002 \\
\hline Stem N allocation \% & $<0.001$ & 0.002 & $<0.001$ & 0.302 & $<0.001$ & 0.026 \\
\hline Root N allocation \% & 0.007 & 0.083 & 0.625 & 0.034 & 0.040 & 0.005 \\
\hline Seedling total P uptake & 0.049 & $<0.001$ & 0.223 & 0.001 & 0.001 & 0.194 \\
\hline Leaf P allocation \% & 0.118 & 0.127 & 0.009 & $<0.001$ & $<0.001$ & 0.018 \\
\hline Stem P allocation \% & $<0.001$ & $<0.001$ & $<0.001$ & $<0.001$ & 0.177 & 0.038 \\
\hline Root P allocation \% & $<0.001$ & 0.741 & 0.069 & 0.868 & $<0.001$ & 0.034 \\
\hline
\end{tabular}

ratio (significant formulation by application rate interactions - Tab. 2). In comparison, the relationship of nutrient uptake with application rate was more consistent with the highest $\mathrm{N}$ and $\mathrm{P}$ uptake observed at the $\mathrm{A} 3$ treatment in both species.

More $\mathrm{N}$ and $\mathrm{P}$ were allocated to leaf and root than to stem (Fig. 2) in both species. Most allocation variables significantly changed with CRF formulation and application rate (Tab. 2), but the general trends differed by species, biomass components and nutrient types (Fig. 2). For example, root $\mathrm{N}$ and $\mathrm{P}$ allocations increased, while stem $\mathrm{P}$ allocation decreased with the increase of $\mathrm{N}: \mathrm{P}_{2} \mathrm{O}_{5}$ ratio from $\mathrm{F} 1$ to $\mathrm{F} 4$ in Chinese yew seedlings (Fig. 2a, Fig. 2C). The same formulation change, however, reduced leaf $\mathrm{N}$ allocation and increased stem $\mathrm{P}$ allocation in Zhejiang Phoebe seedlings Chinese yew and leaf $\mathrm{N}$ allocation in Zhejiang Phoebe occurred at F2. These trends, however, varied with application rate (significant treatment interactions - Tab. 2).

\section{Nutrient recovery and utilization}

Nutrient recovery decreased with the increase of application rate (A1 to A4, $P<0.01$ in both species), with $\mathrm{N}$ recovery from $23.33 \%$ to $10.11 \%$ and $P$ recovery $5.0 \%$ to $1.77 \%$ in Chinese yew seedlings and $\mathrm{N}$ recovery (Fig. 2b, Fig. 2d). Peak stem N allocation in 
Tab. 3 - Mean comparisons of Taxus chinensis and Phoebe chekiangensis seedling growth and biomass by different application rates of controlled-release fertilizer treatments. (RCD): root collar diameter; (Leaf biomass allocation \%): leaf biomass to seedling biomass ratio; (DQI): Dickson's seedling quality index. Different letters indicate significant difference $(\mathrm{p}<0.05)$ after Tukey test.

\begin{tabular}{|c|c|c|c|c|c|c|c|c|}
\hline \multirow{2}{*}{$\begin{array}{l}\text { Growth } \\
\text { variables }\end{array}$} & \multirow{2}{*}{$\begin{array}{c}\text { Application } \\
\text { treatment }\end{array}$} & \multirow{2}{*}{$\mathrm{n}$} & \multicolumn{3}{|c|}{ Taxus chinensis } & \multicolumn{3}{|c|}{ Phoebe chekiangensis } \\
\hline & & & Mean & SE & diff & Mean & $\mathrm{SE}$ & diff \\
\hline \multirow[t]{4}{*}{ Seedling height $(\mathrm{cm})$} & $\mathrm{A} 1$ & 12 & 87.81 & 4.11 & $\mathrm{bc}$ & 77.81 & 3.01 & C \\
\hline & $\mathrm{A} 2$ & 12 & 89.84 & 4.04 & bc & 82.06 & 7.23 & bc \\
\hline & A3 & 12 & 104.08 & 4.88 & $\mathrm{a}$ & 92.12 & 4.24 & $\mathrm{a}$ \\
\hline & A4 & 12 & 92.6 & 4.43 & b & 87.33 & 3.72 & $a b$ \\
\hline \multirow[t]{4}{*}{$\mathrm{RCD}(\mathrm{mm})$} & $\mathrm{A} 1$ & 12 & 8.38 & 0.38 & b & 11.1 & 0.54 & $a$ \\
\hline & $\mathrm{A} 2$ & 12 & 8.81 & 0.47 & b & 11.71 & 0.68 & a \\
\hline & $\mathrm{A} 3$ & 12 & 9.59 & 0.61 & $\mathrm{a}$ & 11.78 & 0.65 & a \\
\hline & A4 & 12 & 8.84 & 0.42 & b & 11.67 & 0.65 & $\mathrm{a}$ \\
\hline \multirow[t]{4}{*}{ Seedling biomass (g) } & $\mathrm{A} 1$ & 12 & 29.7 & 2.84 & c & 51.5 & 8.81 & c \\
\hline & $\mathrm{A} 2$ & 12 & 35.3 & 4.28 & b & 60.9 & 7.24 & $b$ \\
\hline & A3 & 12 & 43.9 & 6.16 & $\mathrm{a}$ & 67.7 & 7.53 & $\mathrm{a}$ \\
\hline & A4 & 12 & 33.5 & 4.13 & bc & 62.7 & 6.28 & $a b$ \\
\hline \multirow[t]{4}{*}{ Leaf biomass allocation (\%) } & $\mathrm{A} 1$ & 12 & 28.1 & 2.35 & $\mathrm{a}$ & 30.6 & 2.25 & $\mathrm{~b}$ \\
\hline & $\mathrm{A} 2$ & 12 & 28.5 & 2.66 & $\mathrm{a}$ & 32.4 & 1.85 & a \\
\hline & $\mathrm{A} 3$ & 12 & 28.2 & 2.44 & $\mathrm{a}$ & 33.0 & 2.01 & a \\
\hline & A4 & 12 & 28.4 & 1.53 & a & 32.0 & 2.11 & $a b$ \\
\hline \multirow[t]{4}{*}{ Stem biomass allocation (\%) } & $\mathrm{A} 1$ & 12 & 41.8 & 2.32 & $\mathrm{a}$ & 36.8 & 2.48 & c \\
\hline & $\mathrm{A} 2$ & 12 & 41.6 & 1.58 & a & 38.8 & 2.13 & $\mathrm{~b}$ \\
\hline & $\mathrm{A} 3$ & 12 & 39.9 & 4.05 & a & 38.6 & 2.42 & $\mathrm{bc}$ \\
\hline & A4 & 12 & 41.0 & 3.51 & a & 40.9 & 2.31 & $\mathrm{a}$ \\
\hline \multirow[t]{4}{*}{ Root biomass allocation (\%) } & $\mathrm{A} 1$ & 12 & 30.1 & 4.03 & $a$ & 32.5 & 3.11 & $a$ \\
\hline & $\mathrm{A} 2$ & 12 & 30.0 & 3.06 & a & 28.8 & 2.38 & b \\
\hline & $\mathrm{A} 3$ & 12 & 31.9 & 4.99 & $a$ & 28.3 & 1.58 & b \\
\hline & A4 & 12 & 30.5 & 4.47 & $a$ & 27.1 & 2.46 & b \\
\hline \multirow[t]{4}{*}{$R / S$} & $\mathrm{~A} 1$ & 12 & 0.44 & 0.08 & $a$ & 0.48 & 0.07 & $a$ \\
\hline & $\mathrm{A} 2$ & 12 & 0.43 & 0.06 & $a$ & 0.41 & 0.05 & $b$ \\
\hline & $\mathrm{A} 3$ & 12 & 0.48 & 0.11 & $a$ & 0.40 & 0.03 & $b$ \\
\hline & A4 & 12 & 0.45 & 0.09 & $a$ & 0.37 & 0.05 & $\mathrm{~b}$ \\
\hline \multirow[t]{4}{*}{$D Q I$} & $\mathrm{~A} 1$ & 12 & 0.36 & 0.04 & b & 0.72 & 0.13 & $a$ \\
\hline & $\mathrm{A} 2$ & 12 & 0.41 & 0.05 & b & 0.86 & 0.19 & a \\
\hline & $\mathrm{A} 3$ & 12 & 0.52 & 0.08 & $\mathrm{a}$ & 0.85 & 0.10 & a \\
\hline & A4 & 12 & 0.4 & 0.05 & b & 0.8 & 0.10 & $\mathrm{a}$ \\
\hline
\end{tabular}
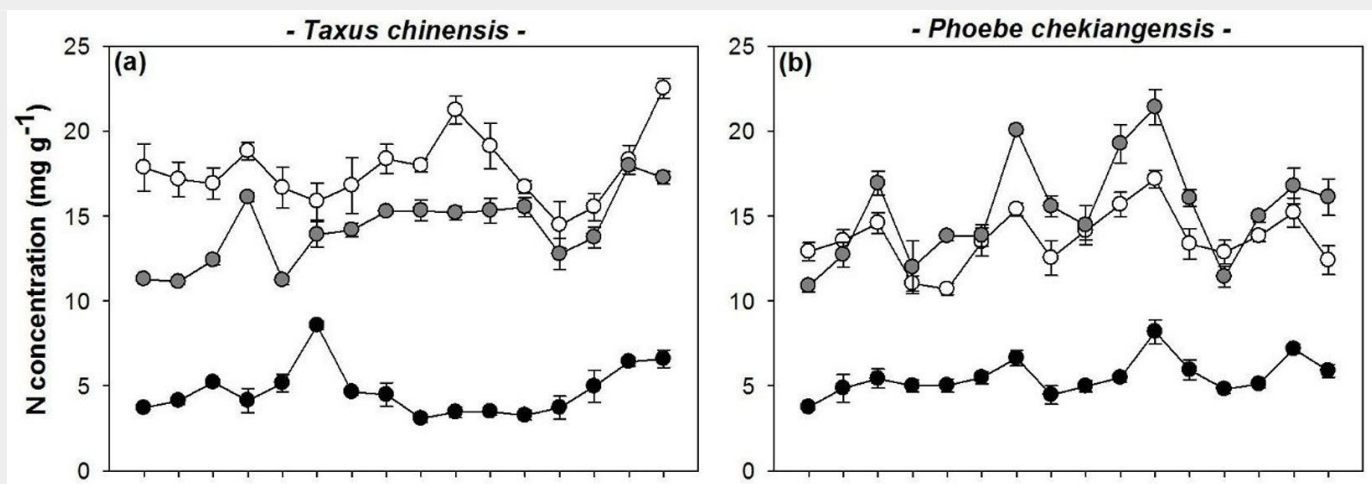

Fig. 1 - $\mathrm{N}$ and $\mathrm{P}$ concentrations in leaves, stems and roots of Taxus chinensis and Phoebe chekiangensis seedlings in response to the interactive effects of controlled-release fertilizer formulation (F1-F4) and application rate (A1A4).
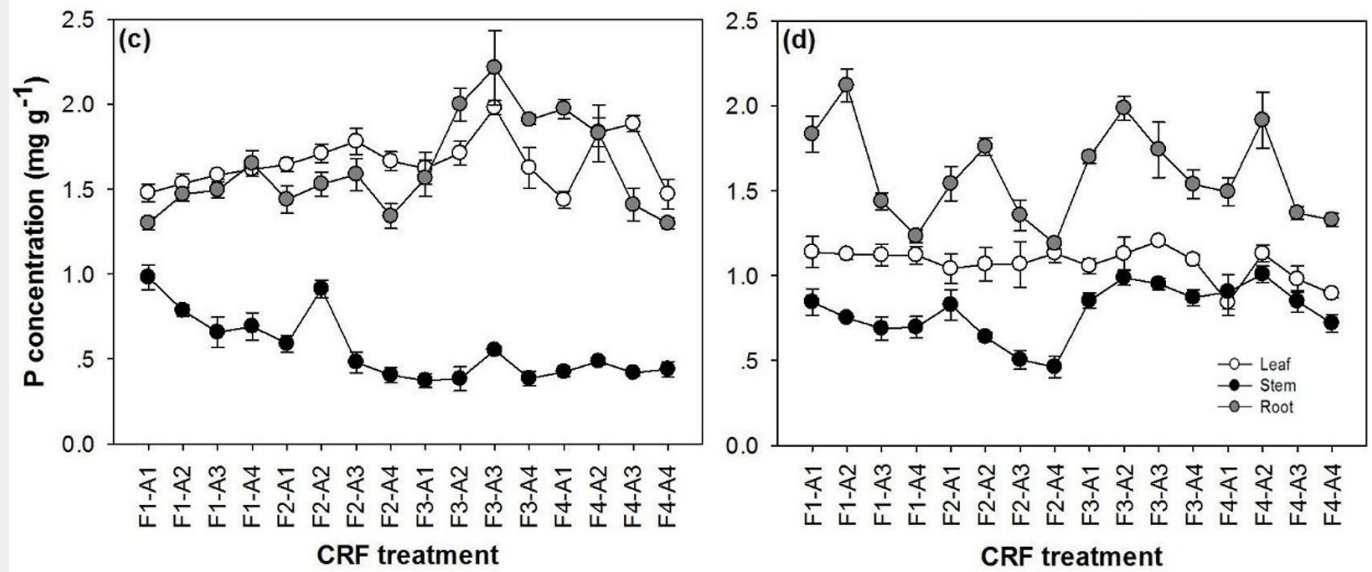
Fig. 2 - $\mathrm{N}$ and $\mathrm{P}$ allocation (\%) to leaves, stems and roots of Taxus chinensis and Phoebe chekiangensis seedlings in response to the interactive effects of controlled-release fertilizer formulation ( $\mathrm{F} 1-\mathrm{F} 4)$ and application rate (A1-A4)
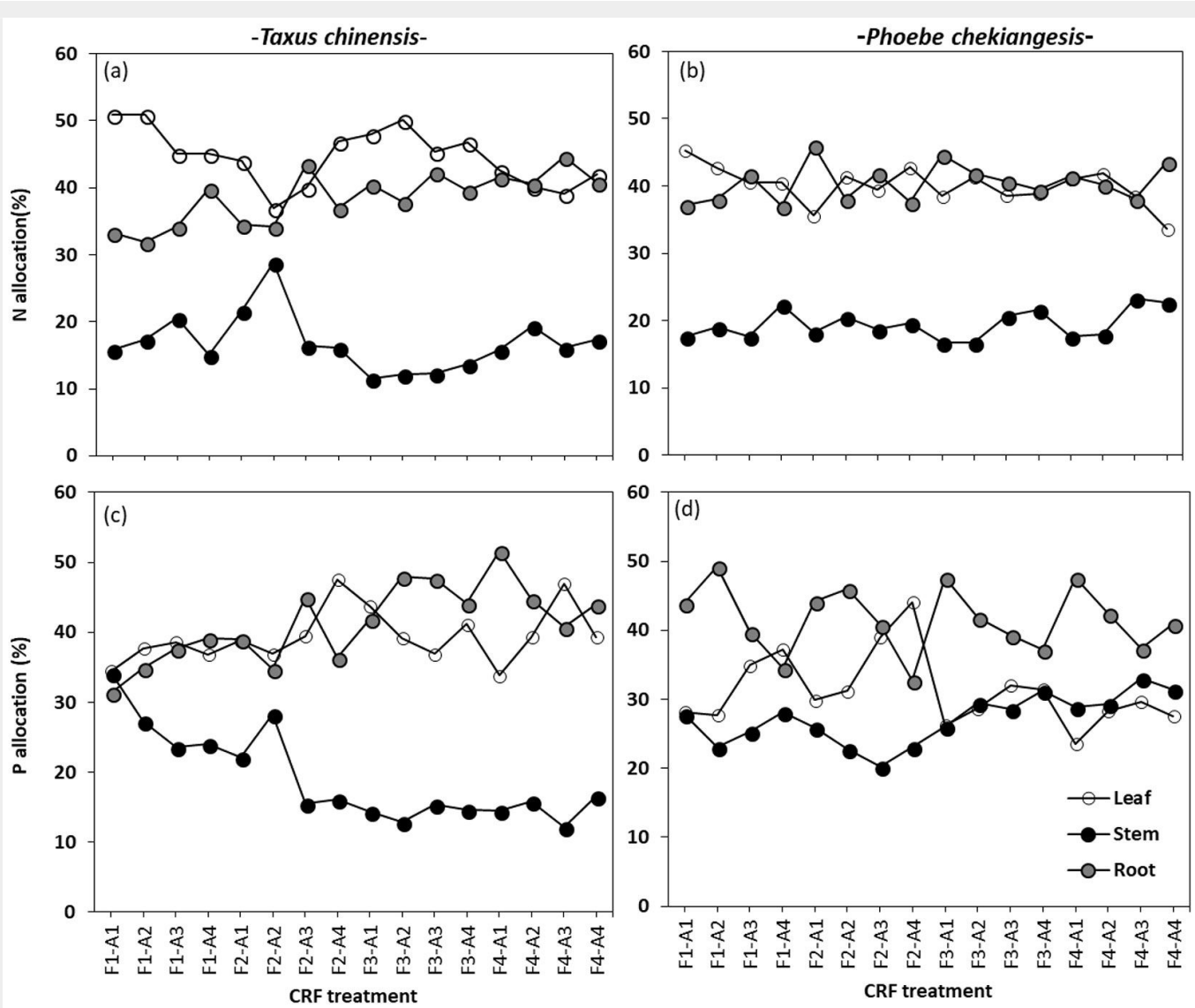

from $38.63 \%$ to $16.12 \%$ and $P$ recovery $8.17 \%$ teractions).

to $2.95 \%$ in Zhejiang Phoebe seedlings, but peaked at formulation $3\left(\mathrm{~F}_{3}\right)$ in both species $(P<0.05$ only in Zhejiang Phoebe). Interactive effect of formulation by application rate was significant only in Chinese yew where the decreasing pattern of $\mathrm{N}$ recovery with application rate was slightly different in F1 and F4.

Nutrient utilization index (UI) was generally highest in the $\mathrm{A} 3$ treatment for Chinese yew (NUI: $6.95 \pm 0.86, P<0.01$; PUl: $68.45 \pm$ 9.04, $P=0.003)$ and the $A 4$ treatments for Zhejiang Phoebe (NUI: $16.08 \pm 2.12, P=0.001$; PUI: $187.09 \pm 22.28, P<0.01)$. The NUI patterns with application rate also varied with formulation in both species (significant in-
In Chinese yew, the utilization efficiency of nutrient uptake (EuU) was only affected by application rate for $\mathrm{N}(P=0.032)$ and formulation for $P(P=0.028)$, with the highest value observed at $A_{4}$ (41.13) and $F_{3}$ (4.27), respectively. In Zhejiang Phoebe, the highest ENUU and EPUU were recorded at $\mathrm{F}_{3}$ (43.02 and 4.23, respectively; $P<0.01$ ) and $\mathrm{A} 3$ orA2 (46.28 and 4.36, respectively; $P<0.01$ ) with some variations (significant interactions).

\section{Association among performance} variables

In Chinese yew seedlings, height, RCD and biomass were positively correlated with $\mathrm{N}$ uptake, $\mathrm{P}$ uptake, $\mathrm{NUI}$ and $\mathrm{PUI}$, but not with leaf $\mathrm{N}$ concentration (Fig. 3a). Comparatively, leaf $\mathrm{P}$ concentration was correlated, not only with height and biomass, but also with DQI. Leaf $\mathrm{N}$ concentration was positively associated with ENUU and EPuU, both of which were negatively correlated with $P$ recovery.

In Zhejiang Phoebe seedlings, correlation was positive between height and leaf $\mathrm{N}+\mathrm{P}$ concentrations, between $\mathrm{N}$ uptake and height + RCD + biomass, between $R / S$ and $\mathrm{N}$ and $\mathrm{P}$ recoveries (Fig. $3 \mathrm{~b}$ ), between $\mathrm{P}$ uptake and RCD + biomass, between $\mathrm{N}+\mathrm{P}$ uptakes and DQI, between biomass and NUI + $\mathrm{PUI}$, and between EnuU + EPuU and $\mathrm{N}+\mathrm{P}$ uptakes, but negative in the relationship of
Fig. 3 - Pearson's correlations among seedling growth and nutritional attributes of height, root-collar diameter (RCD), biomass, root to shoot biomass ratio (RS), Dickson seedling quality index (DQI), leaf $\mathrm{N}$ concentration (leaf $\% \mathrm{~N}$ ), leaf $\mathrm{P}$ concentration (leaf $\% \mathrm{P}$ ), total $\mathrm{N}$ uptake, total $\mathrm{P}$ uptake, $\mathrm{N}$ recovery, $\mathrm{P}$ recovery, $\mathrm{N}$ and $\mathrm{P}$ utilization index (NUI and PUI), and utilization efficiency of $\mathrm{N}$ and $\mathrm{P}$ uptake (ENUU and EPUU). Solid lines indicate positive correlations and dashed lines indicate negative correlations. (a)

- Taxus chinensis -

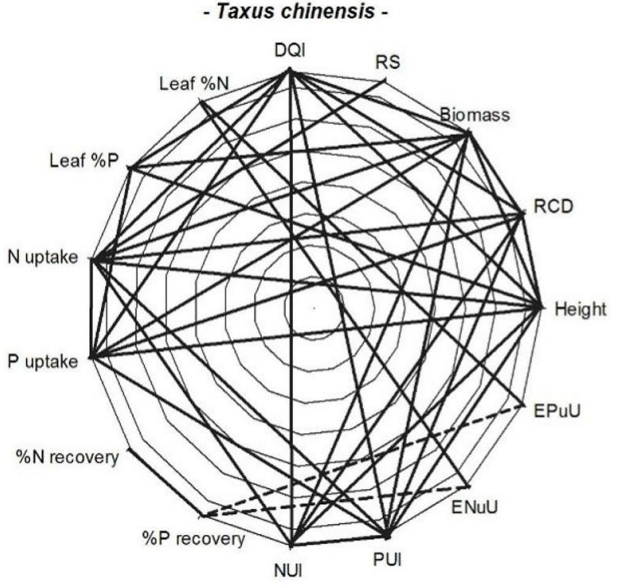

-Phoebe chekiangensis -

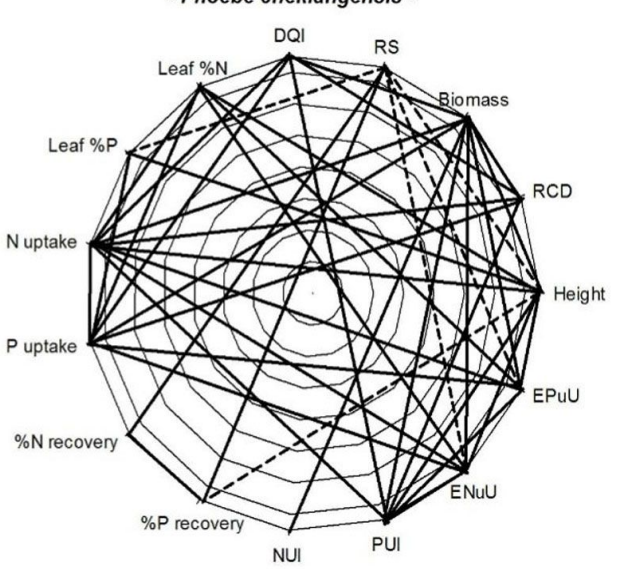


$\mathrm{R} / \mathrm{S}$ with height, leaf $\mathrm{P}$ concentration, ENuU and EPuU.

\section{Discussion}

Our first hypothesis was only partially confirmed by the findings of this study. The change of CRF formulation did not affect seedling size, biomass, and biomass allocation, possibly due to the similar influences of $\mathrm{N}$ and $\mathrm{P}$ on the growth of Chinese yew and Zhejiang Phoebe seedlings. Similar responses were found by Walker \& Huntt (2000) in Pinus jeffreyi seedlings and Oliet et al. (2004) on the root growth of Pinus halepensis seedlings. Our results, however, are different from those by Oliet et al. (2004) who found that high $\mathrm{N}$ ratio promoted shoot growth and therefore reduced R/S ratio in Pinus halepensis seedlings in nursery. Jacobs et al. (2005) and Earnshaw et al. (2016) also indicated that high $\mathrm{N}$ ratio in CRF can enhance biomass accumulation of transplanted seedlings in field conditions. Therefore, despite the significant effect of $\mathrm{N}$ input on tree seedling growth, a higher proportion of $\mathrm{N}$ component in CRF cannot be responsible for the higher quality for tree seedlings of all species.

Although seedling quality index by growth and biomass did not substantially change with formulation, most seedling nutrient variables changed significantly in response to the different formulation levels. Leaf and root nutrient concentrations respond to the change of CRF formulation and contribute heavily to the variation in shoot and root growth (Walker \& Huntt 2000, Oliet et al. 2004). Hawkins (2007) discerned that seedlings with high nutrient utilization index tend to produce more biomass. Similarly, in this study, most of growth variables and DQI were positively related with $\mathrm{N}$ and $\mathrm{P}$ uptakes and PUI (Fig. 3). Our results support the connections between seedling growth and DQI ( $\mathrm{Li}$ et al. 2017).

As expected, seedling height, RCD, biomass, DQI, and nutrient uptake all increased with application rate from $A_{1}$ to $\mathrm{A}_{3}$, consistent with findings by many others (Irino et al. 2004, Klooster et al. 2012, Zamunér Filho et al. 2012, Santelices et al. 2013, Fu et al. 2017). The decrease of growth parameters from $\mathrm{A}_{3}$ to $\mathrm{A}_{4}$ may result from toxic uptake (Oliet et al. 2004). The decrease of nutrient recovery with application rate, as reported by oliet et al. (2004), indicates a greater leachate with increasing nutrient supply (Oliet et al. 2004). With an increase of application rate, only Zhejiang Phoebe demonstrated a common response of plants to resource change where there is a reduction in the biomass allocation to roots (Wang et al. 2013, Crick \& Grime 1987, Hermans et al. 2006), possibly due to greater seedling biomass, than Chinese yew, and therefore pot restriction on root development.

The stronger response of seedling growth to application rate than to the change of $\mathrm{N}: \mathrm{P}_{2} \mathrm{O}_{5}$ ratio suggest that $\mathrm{N}$ and $\mathrm{P}$ elements are equally important to the growth of tree seedlings (Huat et al. 2002, Klooster et al. 2012, Wang et al. 2013, Li et al. 2017), despite some possible influences of formulation on seedling nutrient uptake (Walker \& Huntt 2000, Oliet et al. 2004). The equal significance of $\mathrm{N}$ and $\mathrm{P}$ to Chinese yew and Zhejiang Phoebe seedlings is also revealed from strong correlations of $\mathrm{N}$ and $\mathrm{P}$ concentrations and uptakes with growth and utilization efficiency of nutrient uptake $(\mathrm{EuU})$. In both species, nutrient utilization efficiency was determined primarily by biomass production (Hawkins 2007), as demonstrated from similar treatment response patterns with biomass and strong correlations of utilization index with growth, biomass, and DQI, but not with leaf $\mathrm{N}$ or $\mathrm{P}$ concentrations.

Greater nutrient allocations indicate that leaves and roots are the main nutrient storage of the plants and contribute significantly to new shoot and root growth (Walker \& Huntt 2000, Oliet et al. 2004), as also shown by the positive growth correlation with leaf $\mathrm{N}$ and $\mathrm{P}$ concentrations (Oliet et al. 2004) and uptakes (Fig. 3). Likely, the allocation to leaves would have increased in an earlier season of the year as winter hardening (December) would promote nutrient allocation to stem for winter storage and cold resistance (Zhu et al. 2016, Li et al. 2017).

Substrate property is critical for production of high-quality container seedlings through modified nutrient uptake and utilization. Our study showed a higher nutrient utilization (NUl>4.0 and PUl>50) for both Taxus chinensis and Phoebe chekiangensis relative to the values reported previously, e.g., 1.3-1.8 (Hawkins 2007), 1.5-2.1 (Li et al. 2017), and 1.72-4.74 ( Li et al. 2018) for NUI, and PUI < 40 (Li et al. 2017, 2018). These differences likely result from the differences in potting mixtures that are generally mixed by peat and perlite in previous studies. In our study, the mixing chaff and soil with peat has apparently increased total $\mathrm{N}$, compared to the potting mixtures used by others, e.g., Pinus contorta (1.2 g $\mathrm{kg}^{-1}$ - Amponsah et al. 2004) and Larix olgensis (5.7 $\mathrm{g} \mathrm{kg}^{-1}$ - Wei et al. 2014). The high $\mathrm{N}$ and $\mathrm{P}$ would favor root development and hence help nutrient uptake, utilization, and recovery (10-38\% and 3-9\%, respectively) of the two subtropical seedlings, compared to the nutrient recovery values reported by others, e.g., 17-28\% in Pinus contorta (Amponsah et al. 2004) and 30-56\% in Larix olgensis (Wei et al. 2014). Therefore, the substrate used in this study is appropriate and unlikely has undesired impacts on seedlings.

\section{Conclusions}

The increase of $\mathrm{N}: \mathrm{P}_{2} \mathrm{O}_{5}$ ratio in CRF formulation did not affect seedlings growth, suggesting that $\mathrm{N}$ and $\mathrm{P}$ are equally important to Chinese yew and Zhejiang Phoebe seedlings. The optimum nutritional attributes generally occurred at formulation $\mathrm{F}_{3}$ (17-616 for $\mathrm{N}-\mathrm{P}_{2} \mathrm{O}_{5}-\mathrm{K}_{2} \mathrm{O}$ ), and optimum growth at application rate $\mathrm{A}_{3}\left(3.5 \mathrm{~kg} \mathrm{~m}^{-3}\right)$. The higher $\mathrm{N}: \mathrm{P}_{2} \mathrm{O}_{5}$ ratio $\left(\mathrm{F} 4,19-6-14\right.$ for $\mathrm{N}-\mathrm{P}_{2} \mathrm{O}_{5}-\mathrm{K}_{2} \mathrm{O}$ ) reduced nutrient recovery, utilization index, and utilization efficiency of uptake, possibly due to $\mathrm{P}$ limitation, while higher application rate $\left(\mathrm{A} 4,4.5 \mathrm{~kg} \mathrm{~m}^{-3}\right)$ may have resulted in toxic effects on growth. Different interactive effects of formulation by application rate on nutritional attributes indicate a lack of consistent optimum treatment combination for different nutritional attributes. These findings need to be confirmed through connection of seedling growth and nutrient parameters with field performance.

\section{Acknowledgements}

Thank Rongzhou Man and MyaRice, both from the Ontario Forest Research Institute in Canada, for their polishing work and their suggestions for the paper. This study was supported by the "Forestry Science and Technology Cooperation Project between Zhejiang Province and Chinese Academy of Forestry" (2017SY19), and Special funds for the basic scientific research service of the central public welfare research institute (CAFYBB2018GC003), and "Zhejiang Science and Technology Major Program on Agricultural New Variety Breeding" (2016C02056-3).

\section{References}

Amponsah IG, Lieffers VJ, Comeau PG, Landhäusser SM (2004). Nitrogen-15 uptake by Pinus contorta seedlings in relation to phonological stage and season. Scandinavian Journal of Forest Research 19: 329-338. - doi: 10.1080/028 27580310019301

An BY, Wei HX, Li LL, Guo P (2018). Nutrient uptake and utilization and antioxidants of fruits in red raspberry (Rubus idaeus L.) cultivar "Autumn Bliss" in response to fertilization under extended photoperiod. Notulae Botanicae Hortigrobotanici Cluj-Napoca 46 (2): 440-448. - doi: $10.15835 /$ nbha46211065

Burney OT, Jacobs DF (2011). Ungulate herbivory of regenerating conifers in relation to foliar nutrition and terpenoid production. Forest Ecology and Management 262: 1834-1845. - doi: 10.1016/j.foreco.2011.07.035

Chen YJ, Chen CY, Shen YC (1999). New toxoids from the seeds of Taxus chinensis. Journal of Natural Products 62: 149-151. - doi: 10.1021/np98 02365

Chu XL, Zhang SG, Sun XM, Xu Y (2012). Mineral nutrition efficiency of controlled release fertilizers in net container seedlings of Larix kampferi Sarg. Journal of Beijing Forestry University 34 (6): 47-54. [in Chinese with English Abstract] Crick JC, Grime JP (1987). Morphological plasticity and mineral nutrition capture in two herbaceous species of contrasted ecology. New Phytologist 107: 403-414. - doi: 10.1111/j.1469-8137.19 87.tbo0192.x

Deng QS, Zhu QQ, Lu CH (2008). Natural regeneration of Taxus chinensis var. mairei and its seed dispersal by frugivorous birds. Chinese Journal of Ecology 27 (5): 712-717. [in Chinese 
with English Abstract]

Devine WD, Harrington CA, Leonard LP (2007). Post-planting treatment increase growth of Oregon white oak (Quercus garryana Dougl. Ex Hook.) seedlings. Restoration Ecology 15: 212222. - doi: 10.1111/j.1526-100X.2007.00205.X

Dickson A, Leaf Al, Hosner JF (1960) Quality appraisal of white spruce and white pine seedling stock in nurseries. The Forestry Chronicle 36: 10-13. - doi: 10.5558/tfc36010-1

Duan J, Xu CY, Jacobs DF, Ma LY, Wei HX, Jiang LN, Ren J (2013). Exponential nutrient loading shortens the cultural period of Larix olgensis seedlings. Scandinavian Journal of Forest Research 28 (5): 409-418. - doi: 10.1080/02827581. 2013.778328

Earnshaw KM, Baribault TW, Jacobs DF (2016). Alternative field fertilization techniques to promote restoration of leguminous Acacia koa on contrasting tropical sites. Forest Ecology and Management 376: 126-134. - doi: 10.1016/j.for eco.2016.06.012

Fu YL, Oliet JA, Li GL, Wang JX (2017). Effect of controlled release fertilizer type and rate on mineral nutrients, non-structural carbohydrates, and field performance of Chinese pine container-grown seedlings. Silva Fennica 51 (2): 1607. - doi: 10.14214/sf.1607

Hawkins BJ (2007). Family variation in nutritional and growth traits in Douglas-fir seedlings. Tree Physiology 27: 911-919. - doi: 10.1093/treephys/ 27.6.911

Hawkins BJ, Burgess D, Mitchell AK (2005). Growth and nutrient dynamics of western hemlock with conventional or exponential greenhouse fertilization and planting in different fertility conditions. Canadian Journal of Forest Research 35: 1002-1016. - doi: 10.1139/X05-026

He B, Li YG, Ni ZX, Xu LA (2017). Transcriptome sequencing and SNP detection in Phoebe chekiangensis. PeerJ 5: e3193. - doi: 10.7717/peerj.31 93

Hermans C, Hammond JP, White PJ, Verbruggen $N$ (2006). How do plants respond to nutrient shortage by biomass allocation? Trends in Plant Science 11 (12): 610-617. - doi: 10.1016/j.tplants. 2006.10.007

Huat OK, Awang K, Hashim A, Majid NM (2002). Effects of fertilizers and vesicular-arbuscular mycorrhizas on the growth and photosynthesis of Azadirachta excels (Jack) Jacobs seedlings. Forest Ecology and Management 158: 51-58. doi: 10.1016/S0378-1127(00)00668-X

Irino KO, Iba Y, Ishizuka S, Kenzo T, Ripot S, Kendawang JJ, Miyashita N, Nara K, Hogetsu T, Ninomiya I, Iwasaki K, Sakurai K (2004). Effects of controlled-release fertilizer on growth and ectomycorrhizal colonization of pot-grown seedlings of the dipterocarp Dryobalanops lanceolata in a tropical nursery. Soil Science and Plant Nutrition 50 (5): 747-753. - doi: 10.1080/ 00380768.2004 .10408531

Irino KO, Kang Y, Tanaka K, Hattori D, Ishizuka S, Ninomiya I, Iwasaki K, Kendawang JJ, Sakurai K (2005). Performance of pot-grown seedlings of the dipterocarp Dryobalanops lanceolata with controlled-release fertilizer after transplantation to the shifting cultivation land in Sarawak, Malaysia. Soil Science and Plant Nutrition 51 (3): 369-377. - doi: 10.1111/j.1747-0765.2005.tbooo42. $\mathrm{x}$
Jacobs DF, Salifu KF, Seifert JR (2005). Growth and nutritional response of hardwood seedlings to controlled-release fertilization at outplanting. Forest Ecology and Management 214: 28-39. - doi: 10.1016/j.foreco.2005.03.053

Jia XM, Liu XP (2017). Characterization of the complete chloroplast genome of the Chinese yew Taxus chinensis (Taxaceae), an endangered and medicinally important tree species in China. Conservation Genetics Resources 9 (2): 197-199. - doi: 10.1007/s12686-016-0649-1

Klooster WS, Cregg BM, Fernandez RT, Zzokou P (2012). Growth and physiology of deciduous shade trees in response to controlled-release fertilizer. Scientia Horticulturae 135: 71-79. - doi: 10.1016/j.scienta.2011.12.009

Li XW, Gao Y, Wei HX, Xia HT, Chen QX (2017). Growth, biomass accumulation and foliar nutrient status in fragrant rosewood (Dalbergia odorifera TC Chen) seedlings cultured with conventional and exponential fertilizations under different photoperiod regimes. Soil Science and Plant Nutrition 63 (2): 153-162. - doi: 10.1080/00380768.2017.1312518

Li XW, Chen QX, Lei HQ, Wang JW, Yang S, Wei HX (2018). Nutrient uptake and utilization by fragrant rosewood (Dalbergia odorifera) seedlings cultured with oligosaccharide addition under different lighting spectra. Forests 9: 29. doi: 10.3390/f9010029

Morikawa CK, Saigusa M, Nakanishi H, Nishizawa NK, Mori S (2006). Overcoming Fe deficiency in guava (Psidium guajava L.) by co-situs application of controlled release fertilizers. Soil Science and Plant Nutrition 52: 754-759. - doi: 10.1111/j.1747-0765.2006.00088.x

Oliet J, Planelles R, Segura ML, Artero FM, Jacobs DF (2004). Mineral nutrition and growth of containerized Pinus halepensis seedlings under controlled-release fertilizer. Scientia Horticulturae 103: 113-129. - doi: 10.1016/j.scienta.20 04.04.019

Oskarsson $\mathrm{H}$, Sigurgeirsson A, Raulund-Rasmussen $\mathrm{K}$ (2006). Survival, growth, and nutrition of tree seedlings fertilized at planting on Andisol soils in Iceland: six-year results. Forest Ecology and Management 229: 88-97. - doi: 10.1016/j.for eco.2006.03.018

Reddell P, Webb MJ, Poa D, Aihuna D (1999). Incorporation of slow-release fertilisers into nursery media. New Forests 18: 277-287. - doi: 10.1023/A:1006693308681

Ruthrof KX, Douglas TK, Calver MC, Barber PA, Dell B, St Hardy J GE (2010). Restoration treatments improve seedling establishment in a degraded Mediterranean-type Eucalyptus ecosystem. Australian Journal of Botany 58: 646-655. doi: 10.1071/BT102110067-1924/10/080646

Santelices R, Espinoza S, Ariza AC, Peña-Rojas K, Donoso SR (2013). Effect of shading and fertilization on the development of container-grown Nothofagus glauca seedlings, a threatened species from central Chile. Southern Forests 75 (3): 145-148. - doi: 10.2989/20702620.2013.816234

Sloan JL, Jacobs DF (2012). Leaf physiology and sugar concentrations of transplanted Quercus rubra seedlings in relation to nutrient and water availability. New Forests 43: 779-790. - doi: 10.1007/s11056-012-9326-8

Sloan JL, Jacobs DF (2013). Fertilization at planting influences seedling growth and vegetative competition on a post-mining boreal reclamation site. New Forests 44 (5): 687-701. - doi: 10.1007/s11056-013-9378-4

Thomas P, Li N, Christian T (2013). Taxus chinensis. The IUCN Red List of Threatened Species 2013, eT42548A2987120, Web site. - doi: 10.23 05/IUCN.UK.2013-1.RLTS.T42548A2987120.en

Walker RF, Huntt C (2000). Production of containerized Jeffrey pine plantation stock for harsh sites: growth and nutrition as influenced by controlled-release fertilization. Western Journal of Applied Forestry 15 (2): 86-91. [online] URL: http://academic.oup.com/wjaf/articl e/15/2/86/4741277

Wang Y, Wang XH, Wu XL, Zhang LZ, Wu LR, Xu YM, Zhou ZC (2013). Effects of slow-release fertilizer loading on growth and construction of nutrients reserves of Phoebe chekiangensis and Phoebe bournei container seedlings. Scientia Silvae Sincae 49 (12): 57-63. [online] URL: http://www.cabdirect.org/cabdirect/abstract/2 0143317850

Wei HX, Ren J, Zhou JH (2013). Effect of exponential fertilization on growth and nutritional status in Buddhist pine (Podocarpus macrophyllus [Thunb. ] D. Don) seedlings cultured in natural and prolonged photoperiods. Soil Science and Plant Nutrition 59: 933-941. - doi: 10.1080/ 00380768.2013.864957

Wei HX, Xu CY, Wang WJ, Duan J, Jiang LN (2014). Short-term nitrogen (N)-retranslocation within Larix olgensis seedlings is driven to increase by $\mathrm{N}$-deposition: evidence from a simulated $15 \mathrm{~N}$ experiment in Northeast China. International Journal of Agriculture and Biology 16: 1031-1040. [online] URL: http://www.researchga te.net/publication/274899961

World Conservation Monitoring Centre (1998). Phoebe chekiangensis. The IUCN Red List of Threatened Species, eT32438A9707020, Web site. - doi: 10.2305/IUCN.UK.1998.RLTS.T32438 A9707020.en

Xiao Y, Chu XL, Wang XH, Zhang DB, Ye DW, Zhou ZC (2015). Effect of slow release fertilizer loading on growth and N, P accumulation of container growing seedlings for three precious tree species. Forest Research 28 (6): 781-787. [in Chinese with English Abstract]

Yu JH, Wang CJ, Han SJ, Wang QG, Nie SM (2014). A model-based method to evaluate the ability of nature reserves to protect endangered tree species in the context of climate change. Forest Ecology and Management 327: 48-54. - doi: 10.1016/j.foreco.2014.04.020

Yuan DM, Lin L, Yan CF, Wu Y, Cao LG, Liu QH, Zhou ZC (2012). Afforestation effect of three species of seedlings growing with light media in net Container. Journal of Northeast Forestry University 40 (3): 19-23. [in Chinese with English Abstract] [online] URL: http://www.cabdirect. org/cabdirect/abstract/20123203447

Zamunér Filho AN, Venturin $\mathrm{N}$, Pereira AV, Pereira EB, Macedo RL (2012). Doses of controlled-release fertilizer for production of rubber tree rootstocks. Cerne 18 (2): 239-245. - doi: 10.1590/S0104-77602012000200008

Zang M, Qiu XL, Liu ZL, Wang Q, Lin HC, Zhong Y (2017). Analysis of population structure and spatial distribution Pattern of Phoebe chekiangensis in Sanqingshan mountain of Jiangxi Province. Journal of Anhui Normal University 
(Natural Science) 40 (5): 469-472. [in Chinese with English Abstract] - doi: 10.14182/J.cnki.10 01-2443.2017.05.010

Zhao Y, Dong WY, Zhang ZY, Li JY, Nie LS, Shen YB (2010). Effects of fertilization on seedling growth and photosynthesis of hybrid clone seedlings of Populus tomentosa. Scientia Silvae Sinicae 46 (4): 70-77.

Zhu KY, Liu HC, Wei HX, Zhou JH, Zou QC, Ma GY, Zhang JQ (2016). Prediction of nutrient leach- ing from culture of containerized Buddhist pine and Japanese maple seedlings exposed to extended photoperiod. International Journal of Agriculture and Biology 18: 425-434. - doi: 10.17957/IJAB/15.0108 